\title{
Oceanobacillus aidingensis sp. nov., a moderately halophilic bacterium
}

\author{
Wenyan Liu $\cdot$ Su Sheng Yang
}

Received: 21 November 2013/Accepted: 28 January 2014/Published online: 5 March 2014

(C) The Author(s) 2014. This article is published with open access at Springerlink.com

\begin{abstract}
Two Gram-positive, rod-shaped moderately halophilic bacterial strains, designated $\mathrm{AD} 7-25^{\mathrm{T}}$ and $\mathrm{AB}-11$, were isolated from Aiding and Manasi salt lakes in Xinjiang of China, respectively. The strains were found to be able to grow at $\mathrm{NaCl}$ concentrations of 0-21\% (w/v), with optimum growth occurring at 6-8 \% (w/v) $\mathrm{NaCl}$. The optimal temperature and $\mathrm{pH}$ for growth were determined to be $33-37^{\circ} \mathrm{C}$ and $\mathrm{pH}$ 7.0-7.5. Cells of the strains are motile by means of polar flagella. Both strains can produce ellipsoidal spores. The major cellular fatty acids were identified as anteiso$\mathrm{C}_{15: 0}$, iso- $\mathrm{C}_{15: 0}$, iso- $\mathrm{C}_{14: 0}$, anteiso- $\mathrm{C}_{17: 0}$ and iso- $\mathrm{C}_{16: 0}$. The diamino acid in the peptidoglycan and the major quinone system were determined to be meso-
\end{abstract}

Electronic supplementary material The online version of this article (doi:10.1007/s10482-014-0128-1) contains supplementary material, which is available to authorized users.

W. Liu

National Engineering Laboratory of Biohydrometallurgy, General Research Institute for Nonferrous Metals, Beijing 100088, People's Republic of China e-mail:wyliu35@yahoo.com.cn

\section{W. Liu $\cdot$ S. S. Yang $(\bowtie)$}

Department of Microbiology and Immunology, College of Biological Sciences, China Agricultural University, Key Laboratory for Agro-Microbial Resource and Application, Ministry of Agriculture, Beijing 100193,

People's Republic of China

e-mail: yangssh@cau.edu.cn diaminopimelic acid (meso-DAP) and MK-7, respectively. The DNA G+C contents of stains $\mathrm{AD} 7-25^{\mathrm{T}}$ and AB-11 were 39.8 and 40.0 mol\%, respectively. Phylogenetic analysis based on 16S rRNA gene sequences revealed that these two novel strains are closely related to the genus Oceanobacillus showing 90-99.5\% similarity with respect to type strains. These two novel strains were most closely related to Oceanobacillus oncorhynchi subsp. incaldanensis DSM $16557^{\mathrm{T}}(99.1$ and $99.5 \%$ ), followed by $O$. oncorhynchi subsp. oncorhynchi JCM $12661^{\mathrm{T}}$ (99.1 and $\left.99.4 \%\right)$, Oceanobacillus neutriphilus CGMCC $1.7693^{\mathrm{T}}$ (97.0 and $97.5 \%$ ), Oceanobacillus sojae JCM $15792^{\mathrm{T}}$ (97.6 and $98.0 \%)$ and Oceanobacillus locisalsi KCTC $13253^{\mathrm{T}}$ (96.5 and $96.9 \%)$. The DNA-DNA hybridization data indicated that DNA relatedness between strains AD7$25^{\mathrm{T}}$ and $\mathrm{AB}-11$ was $91.0 \%$, and the genomic homology of representative strain $\mathrm{AD} 7-25^{\mathrm{T}}$ with $O$. oncorhynchi subsp. incaldanensis DSM $16557^{\mathrm{T}}$, O. oncorhynchi subsp. oncorhynchi JCM $12661^{\mathrm{T}}$, O. neutriphilus CGMCC $1.7693^{\mathrm{T}}$, O. sojae JCM $15792^{\mathrm{T}}$ and $O$. locisalsi $\mathrm{KCTC} 13253^{\mathrm{T}}$ were 41, 39, 20, 23 and $17 \%$, respectively. On the basis of phenotypic and phylogenetic distinctiveness, strains $\mathrm{AD} 7-25^{\mathrm{T}}$ and $\mathrm{AB}-11$ should be assigned to the genus Oceanobacillus as a new species, for which the name Oceanobacillus aidingensis sp. nov. was proposed. The type strain is AD7-25 ${ }^{\mathrm{T}}\left(=\mathrm{CGMCC} 1.9106^{\mathrm{T}}=\mathrm{NBRC} 105904^{\mathrm{T}}\right)$.

Keywords Oceanobacillus aidingensis sp. nov · Moderate halophile · Gram-positive · Salt lake 


\section{Introduction}

Molecular and chemotaxonomic analyses have shown that the Gram-positive, rod-shaped and spore-forming moderately halophilic bacteria, which have been isolated from various saline or hypersaline environments (Ventosa et al. 1998; Kim et al. 2007), form several phylogenetically distinct lineages within the family Bacillaceae. Many new genera of this kind of bacteria have been reported along with more research ongoing. The genus Oceanobacillus was first described by Lu et al. (2001) with the type species Oceanobacillus iheyensis DSM $14371^{\mathrm{T}}$ isolated from a deep-sea mud sample. The genus description was later amended due to the isolation of Oceanobacillus oncorhynchi subsp. oncorhynchi JCM $12661^{\mathrm{T}}$ from the skin of a rainbow trout (Yumoto et al. 2005) and the reclassification of Virgibacillus picturae (Heyrman et al. 2003) asOceanobacillus picturae DSM $14867^{\mathrm{T}}$ (Lee et al. 2006) isolated from samples of biofilm formation on mural paintings. At the time of writing, twelve Oceanobacillus species including two subspecies are recognized. In addition to the three species mentioned above, $O$. oncorhynchi subsp. incaldanensis DSM $16557^{\mathrm{T}}$ was isolated from an algal mat collected from a sulfurous spring (Romano et al. 2006), O. profundus DSM $18246^{\mathrm{T}}$ from deep-sea sediment (Kim et al. 2007), O. chironomi DSM $18262^{\mathrm{T}}$ from a chironomid egg mass (Raats and Halpern 2007), O. caeni KCTC $13061^{\mathrm{T}}$ from activated sludge of a wastewater treatment system (Nam et al. 2008), O. kapialis KCTC $13177^{\mathrm{T}}$ from fermented shrimp paste (Namwong et al. 2009), O. neutriphilus CGMCC $1.7693^{\mathrm{T}}$ from activated sludge of a bioreactor (Yang et al. 2010), O. sojae JCM $15792^{\mathrm{T}}$ from the bottom of a mold fermenter from the process of soy sauce production (Tominaga et al. 2009), O. locisalsi KCTC $13253^{\mathrm{T}}$ from a marine solar saltern (Lee et al. 2010), O. indicireducens JCM $17251^{\mathrm{T}}$ (Hirota et al. 2013a) from a fermented Polygonum Indigo liquor sample, $O$. chungangensis KCTC $33035^{\mathrm{T}}$ from a sand dune (Lee et al. 2013) and O. polygoni JCM $17252^{\mathrm{T}}$ from a fermented Polygonum indigo (Hirota et al. $2013 a, b)$. The main characteristics of the genus Oceanobacillus are as follows: Gram-positive, motile and rod-shaped bacteria, facultatively or obligatory and extremely halotolerant or halophilic. They are also catalase positive but oxidase variable. Voges-Proskauer reaction, indole and $\mathrm{H}_{2} \mathrm{~S}$ production and use of citrate are negative. The major cellular fatty acids are anteiso- $\mathrm{C}_{15: 0}$ and iso- $\mathrm{C}_{15: 0}$. The main menaquinone type is MK-7. The DNA $\mathrm{G}+\mathrm{C}$ content range is $35.8-40.1 \mathrm{~mol} \%$. The aim of the present study was to elucidate the taxonomic position, using a polyphasic taxonomic approach, of two Gram-positive, rodshaped moderately halophilic bacterial strains, designated $\mathrm{AD} 7-25^{\mathrm{T}}$ and $\mathrm{AB}-11$, isolated from Aiding and Manasi salt lakes in Xinjiang of China, respectively.

\section{Materials and methods}

Isolation, morphological and physiological characterization

Two strains, $\mathrm{AD} 7-25^{\mathrm{T}}$ and $\mathrm{AB}-11$, were isolated from sediments of Aiding Salt Lake $\left(89^{\circ} 10^{\prime} 32^{\prime \prime}-\right.$ $89^{\circ} 54^{\prime} 32^{\prime \prime} \mathrm{E} \quad 42^{\circ} 32^{\prime} 10^{\prime \prime}-42^{\circ} 49^{\prime} 13^{\prime \prime} \mathrm{N}, 127.8 \mathrm{~g} / 1 \mathrm{Na}^{+}$, $0.5 \mathrm{~g} / \mathrm{l} \mathrm{K}^{+}, \quad 0.1 \mathrm{~g} / \mathrm{lCa}^{2+}, \quad 0.6 \mathrm{~g} / \mathrm{l} \mathrm{Mg}^{2+}, \quad 177.5 \mathrm{~g} / \mathrm{l}$ $\left.\mathrm{Cl}^{-}\right)$and Manasi salt lake $\left(85^{\circ} 37^{\prime} 3^{\prime \prime}-86^{\circ} 16^{\prime} 20^{\prime \prime} \mathrm{E}\right.$ $45^{\circ} 37^{\prime} 50^{\prime \prime}-45^{\circ} 5^{\prime} 47^{\prime \prime} \mathrm{N}, 52.4 \mathrm{~g} / \mathrm{l} \mathrm{Na}^{+}, 11.3 \mathrm{~g} / \mathrm{l} \mathrm{K}^{+}$, $44.6 \mathrm{~g} / \mathrm{l} \mathrm{Mg}^{2+}, 192.9 \mathrm{~g} / \mathrm{l} \mathrm{Cl}^{-}$) of Xinjiang in China, respectively. For isolation, the samples were suspended in sterilized water supplied with $2 \%(\mathrm{w} / \mathrm{v})$ $\mathrm{NaCl}$, serially diluted, spread on improved Gibbson medium (Xu et al. 1995; also used for maintenance), which contained (per litre): $5 \mathrm{~g}$ tryptone, $10 \mathrm{~g}$ yeast extract, $5 \mathrm{~g}$ casein, $2 \mathrm{~g} \mathrm{KCl}, 20 \mathrm{~g} \mathrm{MgSO}_{4} \cdot 7 \mathrm{H}_{2} \mathrm{O}, 20 \mathrm{~g}$ $\mathrm{NaCl}, 3 \mathrm{~g}$ trisodium citrate, and then adjusted to $\mathrm{pH}$ 7.4. O. oncorhynchi subsp. incaldanensis DSM $16557^{\mathrm{T}}$, O. oncorhynchi subsp. oncorhynchi JCM $12661^{\mathrm{T}}$, O. chironomi DSM $18262^{\mathrm{T}}$ and $O$. neutriphilus CGMCC $1.7693^{\mathrm{T}}$ were obtained from the culture collections indicated and used as controls in the phenotypic tests.

Based on the proposed minimal standards for the description of aerobic, endospore-forming bacteria (Logan et al. 2009), standard tests were performed for phenotypic characterisation of strains $\mathrm{AD} 7-25^{\mathrm{T}}$ and AB-11. Cell morphology was detected after cultivation in improved Gibbson medium for $16 \mathrm{~h}$. The endospores were detected after $48 \mathrm{~h}$ by using a phasecontrast optical microscope (ECLIPSE 50i, Nikon). Transmission electron microscopy (JEM 1230) was used for observing bacterial flagellation. Gram reaction was determined according to the methodology used by Gregersen (1978) and the result was confirmed by the methods described by Doetsch (1981). 
The presence of endospores was investigated by using the Schaeffer-Fulton staining method (Murray et al. 1994). Colony morphology was examined after 3 days incubation at $33{ }^{\circ} \mathrm{C}$ on improved Gibbson medium. The growth conditions such as $\mathrm{pH}$ range, $\mathrm{NaCl}$ concentrations and temperature range were estimated in improved Gibbson medium by monitoring the increase in optical density at $600 \mathrm{~nm}$. Growth was detected over the temperature range of $4-55{ }^{\circ} \mathrm{C}$ (4 and $5-55^{\circ} \mathrm{C}$ using increments of $5{ }^{\circ} \mathrm{C}$ ) by incubating under conditions of $6 \% \mathrm{NaCl}(\mathrm{w} / \mathrm{v})$ and $\mathrm{pH}$ 7.2. Growth at various $\mathrm{NaCl}$ concentrations was tested in the range of $0-25 \%(\mathrm{w} / \mathrm{v}) \mathrm{NaCl}[0,0.1,0.2$, $0.3,0.4,0.5 \%(\mathrm{w} / \mathrm{v})$ and $1-25 \%(\mathrm{w} / \mathrm{v})$, using increments of $1 \%$ ] by incubating under conditions of $33{ }^{\circ} \mathrm{C}$ and $\mathrm{pH}$ 7.2. The $\mathrm{pH}$ values for growth were tested in the range of 5.0-11.0 (using increments of $0.5 \mathrm{pH}$ units) by incubating under conditions of $33^{\circ} \mathrm{C}$ and $6 \% \mathrm{NaCl}(\mathrm{w} / \mathrm{v})$. For $\mathrm{pH}$ experiments, the buffers described by Chen et al. (2007) were used. Growth under anaerobic conditions was determined after incubation in a $\mathrm{CO}_{2}$ incubator on anaerobically prepared maintenance medium. Oxygen requirement, activities of catalase, urease and oxidase, hydrolysis of casein, starch, tyrosine, Tween 80, aesculin, xanthine and hypoxanthine, nitrate reduction, Voges-Proskauer test, methyl red test, indole and $\mathrm{H}_{2} \mathrm{~S}$ production were performed according to the conventional methods described by Cowan and Steel (1965), Lanyi (1987), Smibert and Krieg (1994) and Dong and Cai (2001). Antibiotic susceptibility was determined on a maintenance medium plate with the following concentrations $(\mu \mathrm{g} / \mathrm{ml})$ : rifampicin $(5,10)$, streptomycin $(50,100)$, ampicillin $(30,50)$, gentamicin $(15$, $40)$, chloramphenicol $(10,20)$, kanamycin $(50,100)$, erythromycin $(30,50)$, tetracycline $(10,20)$, spectinomycin $(20,50)$ and nalidixic acid $(15,30)$. Fermentation of 49 carbohydrates, arginine dihydrolase, tryptophan deaminase, phenylalanine deaminase, lysine decarboxylases, ornithine decarboxylases, citrate utilization and hydrolysis of gelatin were determined by using API 20E and API 50CHB microtest galleries systems (bioMérieux). Reference strains were used as controls in the tests. All tests were performed in test tubes ( 3 tubes in parallel) and the tests without inoculation were used as negative controls. Unless otherwise indicated, each test was carried out under the optimal conditions for each strain.
Chemotaxonomic characterization

Biomass of strains $\mathrm{AD} 7-25^{\mathrm{T}}$ and $\mathrm{AB}-11$ for chemotaxonomic analysis was harvested from cultures after incubation on improved Gibbson medium at $33{ }^{\circ} \mathrm{C}$ for $18 \mathrm{~h}$. The analysis of the cell-wall peptidoglycan was carried out with $O$. neutriphilus CGMCC $1.7693^{\mathrm{T}}$ as a reference according to the method described by Schleifer and Kandler (1972) and Schleifer (1985). Cell-wall hydrolysates were separated by one-dimensional chromatography on micro-cellulose thin layers. Menaquinones were analyzed as described previously (Collins 1985) using reverse-phase HPLC (Agilent HPLC-1200). Extraction and analysis of polar lipids by two-dimensional TLC was performed according to Ventosa et al. (1993). Cellular fatty acids were extracted and methylated according to the standard protocol of Sherlock Microbial Identification System version 6.0 (MIDI), analysed by GC (model 6890; Agilent) and identified using the TSBA6 database of the Microbial Identification System (Sasser 1990). The physiological age at the point of harvest of the three bacterial strains tested was the logarithmic growth phase. O. oncorhynchi subsp. oncorhynchi JCM $12661^{\mathrm{T}}$ was used a reference in chemotaxonomic analysis tests.

\section{Molecular characterization}

Chromosomal DNA was extracted and purified according to standard methods (Marmur 1961). The 16S rRNA gene sequences were amplified as described by Duckworth et al. (1996). PCR products were cloned into the pGEM-T easy vector (Promega) and then sequenced with a DNA Sequencer (373A; Applied Biosystems) and analysed by using the software provided by the manufacturer. The almostcomplete 16S rRNA gene sequences of strains AD7$25^{\mathrm{T}}$ and $\mathrm{AB}-11(1,464$ and 1,468 bp) were compared with sequences from the GenBank, EMBL, DDBJ and PDB databases using the BLAST program via the National Center for Biotechnology Information (NCBI). Pairwise sequence similarities were calculated using the BioEdit software package (Hall 1999). Sequence data were aligned with CLUSTAL W (Thompson et al. 1994). Phylogenetic trees were constructed by the neighbour-joining (Saitou and Nei 1987), minimum-evolution (Rzhetsky and Nei 1992) and maximum-parsimony methods (Fitch 1971) with 
the MEGA5 program package (Tamura et al. 2011). Evolutionary distances were calculated according to the algorithm of the Kimura two-parameter model (Kimura 1980) for the neighbour-joining and minimum evolution methods. Bootstrap analysis was used to assess the stability of the relationships by means of 1,000 resamples. The $16 \mathrm{~S}$ rRNA gene sequences used for the phylogenetic comparisons are shown in the neighbour-joining phylogenetic tree with their strain designations and accession numbers.

\section{DNA G + C content and DNA-DNA hybridization}

The determination of DNA G+C content was carried out by the thermal denaturation method using a BIO20 UV spectrophotometer according to Marmur and Doty (1962), and Escherichia coli K-12 was used as a standard. Levels of DNA-DNA relatedness were performed by the thermal denaturation and renaturation method described by De Ley et al. (1970) and modified by Huß et al. (1983). DNAs were sheared by sonication (Braun Melsungen) at $50 \mathrm{~W}$ for three periods of $10 \mathrm{~s}$. The renaturation was performed in $2 \times$ saline-sodium citrate buffer at $68{ }^{\circ} \mathrm{C}$. In total, three replicate hybridizations were carried out.

\section{Results and discussion}

Two Gram-positive moderately halophilic bacterial strains, designated $\mathrm{AD} 7-25^{\mathrm{T}}$ and $\mathrm{AB}-11$, were isolated from salt lakes in Xinjiang of China. The similarity of 16S rRNA gene sequences (GenBank/EMBL/DDBJ accession numbers FJ428529 and GU326362 respectively) between the two novel strains was $99.1 \%$. The 16S rRNA gene sequence comparison indicated that the two strains showed 90-99.5\% similarity with respect to the sequences of type strains of validly named Oceanobacillus species. Strains $\mathrm{AD} 7-25^{\mathrm{T}}$ and AB-11 were found to be most closely related to $O$. oncorhynchi subsp. incaldanensis DSM $16557^{\mathrm{T}}(99.1$ and $99.5 \%$ sequence similarity), followed by $O$. oncorhynchi subsp. oncorhynchi JCM $12661^{\mathrm{T}}(99.1$ and $99.4 \%)$, O. neutriphilus CGMCC $1.7693^{\mathrm{T}}(97.0$ and $97.5 \%$ ), O. sojae $\mathrm{JCM} 15792^{\mathrm{T}}$ (97.6 and $98.0 \%$ ) and $O$. locisalsi KCTC $13253^{\mathrm{T}}$ (96.5 and $\left.96.9 \%\right)$. The sequence similarities with the other Oceanobacillus species were 90-95.2\%. Phylogenetic analysis revealed that strains $\mathrm{AD} 7-25^{\mathrm{T}}$ and $\mathrm{AB}-11$ were on the same phylogenetic branch within the genus Oceanobacillus (Fig. 1). The topologies of the phylogenetic trees built using the minimum-evolution and maximum-parsimony methods also supported the conclusion that strains $\mathrm{AD} 7-25^{\mathrm{T}}$ and $\mathrm{AB}-11$ form a stable clade with the type strains of $O$. oncorhynchi subspecies (Supplementary Fig. S1). On the basis of sequence analysis, it is evident that the novel strains should be assigned to the genus Oceanobacillus.

The DNA-DNA hybridization data revealed that DNA relatedness between strains $\mathrm{AD} 7-25^{\mathrm{T}}$ and $\mathrm{AB}-11$ was $91 \pm 5 \%$. The representative strain $\mathrm{AD} 7-25^{\mathrm{T}}$ and AB-11 shared $41 \pm 9$ and $42 \pm 10 \%$ similarity with $O$. oncorhynchi subsp. incaldanensis DSM $16557^{\mathrm{T}}, 39 \pm 3$ and $39 \pm 7 \%$ with $O$. oncorhynchi subsp. oncorhynchi JCM $12661^{\mathrm{T}}, 20 \pm 4$ and $21 \pm 4 \%$ with $O$. neutriphilus CGMCC $1.7693^{\mathrm{T}}$, $23 \pm 6$ and $25 \pm 7 \%$ with $O$. sojae JCM $15792^{\mathrm{T}}$ and $17 \pm 7$ and $22 \pm 9 \%$ with O. locisalsi KCTC $13253^{\mathrm{T}}$ at the genomic level. The DNA $\mathrm{G}+\mathrm{C}$ contents of strains $\mathrm{AD} 7-25^{\mathrm{T}}$ and $\mathrm{AB}-11$ were determined to be 39.8 and $40.0 \mathrm{~mol} \%$, respectively, which are in the range for the genus Oceanobacillus.

Phenotypic analysis showed that cells of the strains $\mathrm{AD} 7-25^{\mathrm{T}}$ and $\mathrm{AB}-11$ are Gram-positive and rodshaped with a size range of $0.5-0.6 \times 1.2-2.0 \mu \mathrm{m}$. Ellipsoidal endospores were found be formed and the cells to be motile by means of polar flagella (Supplementary Fig. S2). Growth was determined to occur at 4-45 ${ }^{\circ} \mathrm{C}$, pH 6-10 and 0-21\% (w/v) NaCl. Catalase, urease and oxidase tests were found to be positive, but $\beta$-galactosidase was negative. Tween 80 and aesculin were found to be hydrolyzed. $\mathrm{H}_{2} \mathrm{~S}$ and indole were not produced. Nitrate was found to be reduced to nitrite. The Voges-Proskauer test was negative. Acids were found to be produced from D-maltose, D-fructose, Dglucose, D-mannitol, D-galactose, D-lyxose, starch, melibiose and sucrose. The morphological, physiological and biochemical characteristics in detail are given in the species description below. The phenotypic differences between the two novel strains and Oceanobacillus species are shown in Table 1.

The menaquinones were determined to be MK-7 (93.3\%), MK-6 (3.7\%) and MK-6( $\left(\mathrm{H}_{2}\right)$ (3.0\%), respectively. The diamino acid in the peptidoglycan was identified as meso-diaminopimelic acid (mesoDAP). The polar lipids of strain $\mathrm{AD} 7-25^{\mathrm{T}}$ were found to consist of diphosphatidylglycerol, phosphatidylethanolamine and phosphatidylglycerol (Supplementary 
Fig. 1 Phylogenetic tree based on 16S rRNA gene sequences and reconstructed using the neighbour-joining method showing the relationship between the isolates, type strains of Oceanobacillus and species of other closely related genera. Bootstrap values over $50 \%$ are shown at nodes as percentages of 1,000 replications. Bar 0.005 substitutions per site

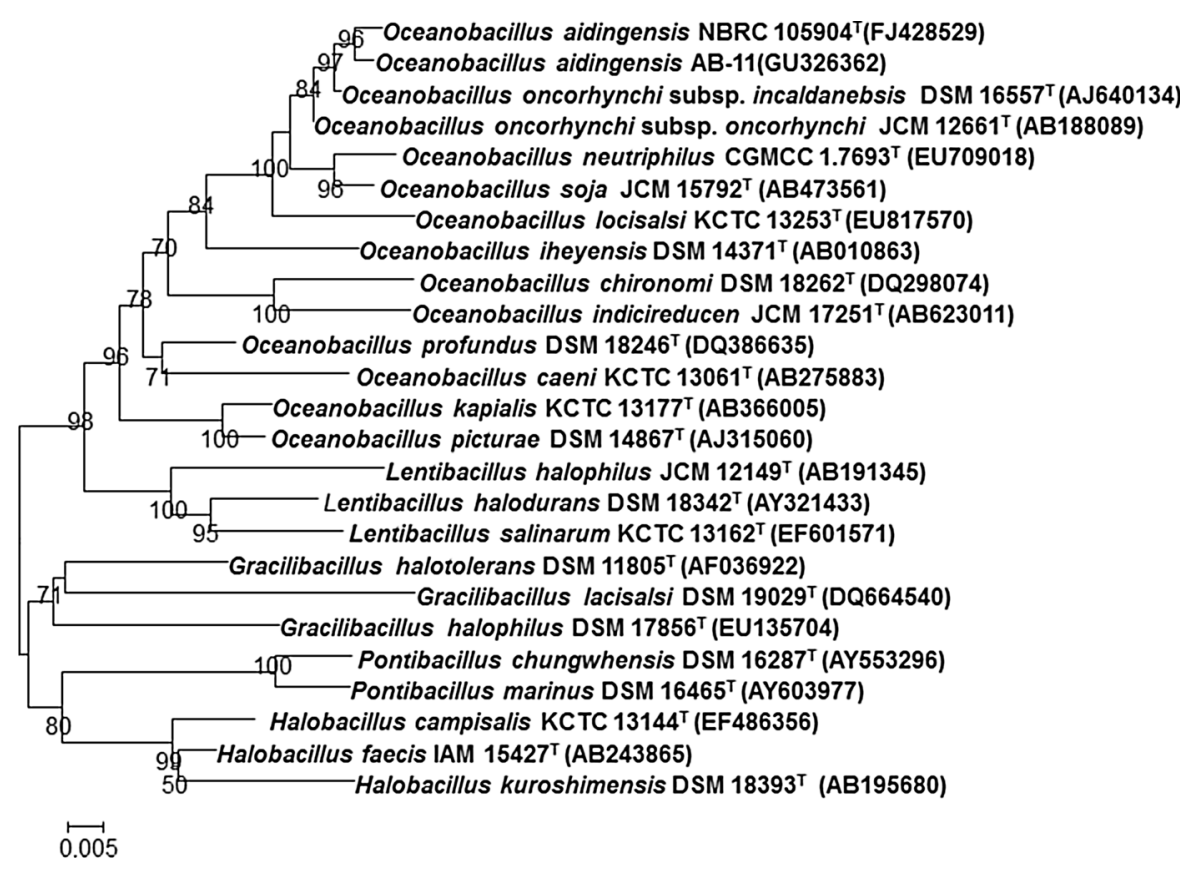

Table 1 Differential phenotypic characteristics of strains AD7-25 $5^{\mathrm{T}}$ (AB-11) and the type strains of some phylogenetically related bacteria

\begin{tabular}{|c|c|c|c|c|c|c|c|}
\hline Characteristic & 1 & 2 & 3 & 4 & 5 & 6 & 7 \\
\hline \multicolumn{8}{|c|}{$\mathrm{NaCl}$ for growth $(\% \mathrm{w} / \mathrm{v})$} \\
\hline Range & $0-21$ & $0-21$ & $0-22$ & $0-17$ & $5-20$ & $0-15$ & $0-25$ \\
\hline Optimum & $6-8$ & $6-8$ & 7 & $3-5$ & 10 & $2-3$ & $5-8$ \\
\hline \multicolumn{8}{|l|}{$\mathrm{pH}$ for growth } \\
\hline Range & $6-10$ & $6-10$ & $9-10$ & $6-9$ & $6.5-9.5$ & $6-10$ & $6-9$ \\
\hline Optimum & $7.0-7.5$ & $7.0-7.5$ & 9 & 7.0 & 9.0 & 8.5 & $7-7.5$ \\
\hline \multicolumn{8}{|l|}{ Acid production from } \\
\hline D-Arabinose & - & - & - & - & - & - & - \\
\hline Galactose & + & + & + & + & - & + & - \\
\hline D-Glucose & + & + & + & + & + & + & + \\
\hline D-Fructose & + & + & + & + & + & + & - \\
\hline Mannitol & + & - & - & + & + & - & + \\
\hline D-Trehalose & - & - & + & + & + & - & - \\
\hline \multicolumn{8}{|l|}{ Hydrolysis of } \\
\hline Aesculin & + & + & - & + & - & - & + \\
\hline Nitrate reduction & + & + & + & - & + & + & + \\
\hline Urease & + & + & - & + & + & - & - \\
\hline$\beta$-Galactosidase & - & - & - & + & + & - & - \\
\hline DNA G+C (mol\%) & 39.8 & 40 & 38.5 & 36.3 & 40.1 & 38 & 39.8 \\
\hline
\end{tabular}

The results are based on the same test conditions. Species 1 , strains AD7-25 $; 2$, AB-11; 3, O. oncorhynchi subsp. oncorhynchi JCM $12661^{\mathrm{T}} ;$, O. neutriphilus CGMCC $1.7693^{\mathrm{T}} ; 5$, O. oncorhynchi subsp. incaldanensis DSM 16557 ${ }^{\mathrm{T}}$; 6, O. sojae JCM $15792^{\mathrm{T}}$; 7, O. locisalsi KCTC $13253^{\mathrm{T}}$. Symbol: + , positive reaction; - , negative reaction 
Table 2 Cellular fatty acid compositions of strains AD7-25 ${ }^{\mathrm{T}}$, AB-11 and Oceanobacillus oncorhynchi subsp. oncorhynchi JCM $12661^{\mathrm{T}}$

\begin{tabular}{|c|c|c|c|c|c|c|c|}
\hline Fatty acid & 1 & 2 & 3 & 4 & 5 & 6 & 7 \\
\hline \multicolumn{8}{|l|}{ Saturated } \\
\hline $\mathrm{C}_{14: 0}$ & 0.2 & 0.3 & 0.2 & 1.4 & 0.1 & 0.2 & $\operatorname{tr}$ \\
\hline $\mathrm{C}_{15: 0}$ & NA & 0.1 & 0.1 & - & 0.5 & 2.1 & - \\
\hline $\mathrm{C}_{16: 0}$ & 1.7 & 1.1 & 1.7 & 4.6 & 2.3 & 1.9 & 2.3 \\
\hline $\mathrm{C}_{17: 0}$ & 2.1 & 3.0 & 1.7 & - & 0.9 & 3.4 & NA \\
\hline $\mathrm{C}_{18: 0}$ & NA & NA & NA & 2.6 & 0.1 & 0.7 & 1.2 \\
\hline \multicolumn{8}{|l|}{ Unsaturated } \\
\hline $\begin{array}{l}\mathrm{C}_{16: 1} \\
\quad \omega 7 c \text { alcohol }\end{array}$ & 0.2 & 0.1 & 0.1 & NA & 0.3 & 0.5 & - \\
\hline \multicolumn{8}{|l|}{ Branched } \\
\hline Iso- $\mathrm{C}_{14: 0}$ & 15.0 & 12.8 & 16.4 & 3.8 & 12.1 & 9.8 & 1.7 \\
\hline Anteiso- $\mathrm{C}_{14: 0}$ & NA & NA & NA & - & 0.4 & 3.0 & NA \\
\hline Iso- $\mathrm{C}_{15: 0}$ & 17.5 & 15.6 & 13.1 & 6.8 & 12.2 & 4.4 & 7.3 \\
\hline Anteiso- $C_{15: 0}$ & 44.5 & 46.2 & 28.3 & 37.7 & 36.5 & 44.6 & 46.2 \\
\hline Iso- $\mathrm{C}_{16: 0}$ & 9.2 & 10.5 & 21.0 & 15.8 & 21.2 & 13.4 & 6.7 \\
\hline Iso- $\mathrm{C}_{17: 0}$ & 1.8 & 2.7 & 3.9 & 4.0 & 2.9 & 1.8 & 4.0 \\
\hline Anteiso- $C_{17: 0}$ & 6.9 & 7.4 & 12.6 & 18.9 & 10.3 & 11.3 & 30.4 \\
\hline
\end{tabular}

Species: 1, Strain $\mathrm{AD} 7-25^{\mathrm{T}}$ (data from this study); 2, Strain AB-11(data from this study); 3, O. oncorhynchi subsp. oncorhynchi JCM $12661^{\mathrm{T}}$ (data from this study); 4, $O$. neutriphilus CGMCC $1.7693^{\mathrm{T}}$ (data from Yang et al. 2010); 5, O. oncorhynchi subsp. incaldanensis DSM $16557^{\mathrm{T}}$ (data from this study); 6, O. sojae JCM $15792^{\mathrm{T}}$ (data from this study); 7, O. locisalsi KCTC $13253^{\mathrm{T}}$ (data from Lee et al. 2010)

NA No data available, $t r$ trace amount, - not detected

Fig. S3). The major cellular fatty acids of strains AD7$25^{\mathrm{T}}$ and $\mathrm{AB}-11$ were identified as anteiso- $\mathrm{C}_{15: 0}(44.5$, $46.2 \%)$, iso- $\mathrm{C}_{15: 0}(17.5,15.6 \%)$, iso- $\mathrm{C}_{14: 0}$ (15.0, $12.8 \%)$, iso- $\mathrm{C}_{16: 0}(9.2,10.5 \%)$ and anteiso- $\mathrm{C}_{17: 0}$ $(6.9,7.4 \%)$, respectively. Detailed information on the cellular fatty acid composition, the difference between strains AD7-25 ${ }^{\mathrm{T}}, \mathrm{AB}-11$ and the reference type strains are provided in Table 2.

Phylogenetic and chemotaxonomic analyses suggested that strains $\mathrm{AD} 7-25^{\mathrm{T}}$ and $\mathrm{AB}-11$ belong to the genus Oceanobacillus. However, the DNA-DNA hybridization, DNA base composition and phylogenetic analysis clearly revealed that the two strains are of the same species but are different from the members of this genus. Furthermore, the two strains can be differentiated from the recognized species according to some phenotypic characteristics, such as enzyme activities, growth conditions, acid production from sugars, hydrolysis reactions and nitrate reduction (Table 1 and Description). As a result, it is considered that the two strains represent a novel species of the genus Oceanobacillus, for which the name Oceanobacillus aidingensis sp. nov. is proposed. The type strain is $\mathrm{AD} 7-25^{\mathrm{T}} \quad\left(=\mathrm{CGMCC} 1.9106^{\mathrm{T}}=\mathrm{NBRC}\right.$ $105904^{\mathrm{T}}$ ).

\section{Description of Oceanobacillus aidingensis sp. nov}

Oceanobacillus aidingensis (ai.ding.en'sis. N.L. masc. adj. aidingensis from Aiding Salt Lake, where the type strain was first isolated).

Cells are rod-shaped with a size range of 0.5-0.6 × 1.2-2.0 $\mu \mathrm{m}$, Gram-positive, occurring singly or in pairs and motile by means of polar flagella. Ellipsoidal endospores are located at a central or subterminal position. Colonies are circular, smooth, entire, cream coloured and $1-3 \mathrm{~mm}$ in diameter after incubating 3 days. Growth occurs at $0-21 \%$ (w/v) total salts, and the optimum is $6-8 \%(\mathrm{w} / \mathrm{v})$. The optimal temperature range for growth is $33-37{ }^{\circ} \mathrm{C}$, and growth occurs at $4-45^{\circ} \mathrm{C}$. The optimal $\mathrm{pH}$ value for growth is 7.0-7.5 and $\mathrm{pH}$ range is $6-10$. Catalase, urease and oxidase are produced but $\beta$-galactosidase, arginine dihydrolase, lysine decarboxylase, tryptophan deaminase and ornithine decarboxylase are absent. Tween 80 and aesculin are hydrolyzed but tyrosine, gelatin, xanthine, hypoxanthine, starch and casein are not hydrolyzed. Nitrate can be reduced to nitrite. Citrate cannot be utilized. $\mathrm{H}_{2} \mathrm{~S}$ and indole can't be produced. Methyl red and Voges-Proskauer reaction (acetoin) are negative. According to the API 50CHB system, acids are produced from D-maltose, Dfructose, D-glucose, D-mannitol, D-galactose, D-lyxose, starch, melibiose and sucrose but not from $\mathrm{N}$-acetylglucosamine, raffinose, arbutine, gentiobiose, cellobiose, D-trehalose, amygdalin, D-mannose, glycerol, Lrhamnose, salicin, D-tagatose, erythritol, adonitol, methyl beta-D-xyloside, L-sorbose, dulcitol, methyl alpha-D-mannoside, methyl alpha-D-glucoside, melezitose, glycogen, xylitol, D-turanose, DL-fucose, 2-ketogluconate, 5-ketogluconate, DL-arabinose, Dribose, DL-xylose, inositol, D-sorbitol, D-adonito, DLarabitol or inulin. Acid production from lactose and gluconate is variable (the type strain is negative). Susceptible to $(\mu \mathrm{g} / \mathrm{ml})$ : rifampicin $(5,10)$, erythromycin (50), kanamycin (100), chloramphenicol (20) and gentamicin (40). But not susceptible to streptomycin 
(50, 100), ampicillin (30, 50), gentamicin (10), chloramphenicol (10), kanamycin (50), erythromycin (30), tetracycline $(10,20)$, spectinomycin $(20,50)$ and nalidixic acid $(10,30)$. The diamino acid in murein is meso-DAP and the major menaquinone is MK-7, with minor amounts of MK-6 and MK-6( $\left.\mathrm{H}_{2}\right)$. Polar lipids of the type strain consist of diphosphatidylglycerol, phosphatidylethanolamine and phosphatidylglycerol. The major cellular fatty acids ( $\geq 1 \%$ of the total) are anteiso- $\mathrm{C}_{15: 0}$, iso- $\mathrm{C}_{15: 0}$, iso- $\mathrm{C}_{14: 0}$, iso- $\mathrm{C}_{16: 0}$, anteiso$\mathrm{C}_{17: 0}, \mathrm{C}_{17: 0}$, iso- $\mathrm{C}_{17: 0}$ and $\mathrm{C}_{16: 0}$, respectively. The DNA $\mathrm{G}+\mathrm{C}$ content of the type strain is $39.8 \mathrm{~mol} \%$.

The type strain, $\mathrm{AD} 7-25^{\mathrm{T}}$ (= CGMCC $1.9106^{\mathrm{T}}$ $=$ NBRC $105904^{\mathrm{T}}$ ), was isolated from the Aiding Salt Lake in Xinjiang, China. The GenBank/EMBL/DDBJ accession number for the 16S rRNA gene sequence of strain $\mathrm{AD} 7-25^{\mathrm{T}}$ is FJ428529.

Acknowledgments This work was supported financially by the China International Cooperation Program for Science and Technology (2006DFA31060). National High-Tech Research and Development Program of China (863 Program 2012AA061501). The authors thank Kristen Lee of Arizona State University for editorial help. We are grateful to Yuguang Zhou (China General Microbiological Culture Collection Center, Institute of Microbiology, Chinese Academy of Sciences), for providing biological samples.

Open Access This article is distributed under the terms of the Creative Commons Attribution License which permits any use, distribution, and reproduction in any medium, provided the original author(s) and the source are credited.

\section{References}

Chen YG, Cui XL, Pukall R, Li HM, Yang YL, Xu LH, Wen ML, Peng Q, Jiang CL (2007) Salinicoccus kunmingensis sp. nov., a moderately halophilic bacterium isolated from a salt mine in Yunnan, south-west China. Int J Syst Evol Microbiol 57:2327-2332

Collins MD (1985) Isoprenoid quinone analysis in classification and identification. In: Goodfellow M, Minnikin DE (eds) Chemical methods in bacterial systematics. Academic Press, London, pp 267-287

Cowan ST, Steel KJ (1965) Manual for the identification of medical bacteria. Cambridge University Press, London

De Ley J, Cattoir H, Reynaerts A (1970) The quantitative measurement of DNA hybridization from renaturation rates. Eur J Biochem 12:133-142

Doetsch RN (1981) Determinative methods of light microscopy. In: Gerhardt P, Murray RGE, Costilow RN, Nester EW, Wood WA, Krieg NR, Phillips GH (eds) Manual of methods for general bacteriology. American Society for Microbiology, Washington, pp 21-33
Dong XZ, Cai MY (2001) Determinative manual for routine bacteriology. Scientific Press, Beijing (English translation)

Duckworth AW, Grant WD, Jones BE, van Steenbergen R (1996) Phylogenetic diversity of soda lake alkaliphiles. FEMS Microbiol Ecol 19:181-191

Fitch WM (1971) Toward defining the course of evolution: minimum change for a specific tree topology. Syst Zool 20:406-416

Gregersen T (1978) Rapid method for distinction of Gramnegative from Gram-positive bacteria. Eur J Appl Microbiol Biotechnol 5:123-127

Hall TA (1999) BioEdit: a user-friendly biological sequence alignment editor and analysis program for Windows 95/98/ NT. Nucleic Acids Symp Ser 41:95-98

Heyrman J, Logan NA, Busse HJ, Balcaen A, Lebbe L, RodriguezDiaz M, Swings J, De Vos P (2003) Virgibacillus carmonensis sp. nov., Virgibacillus necropolis sp. nov. and Virgibacillus picturae sp. nov., three novel species isolated from deteriorated mural paintings, transfer of the species of the genus Salibacillus to Virgibacillus, as Virgibacillus marismortui comb. nov. and Virgibacillus salexigens comb. nov., and emended description of the genus Virgibacillus. Int J Syst Evol Microbiol 53:501-511

Hirota K, Aino K, Nodasaka Y, Yumoto I (2013a) Oceanobacillus indicireducens sp. nov., a facultatively alkaliphile that reduces an indigo dye. Int $\mathrm{J}$ Syst Evol Microbiol 63:1437-1442

Hirota K, Hanaoka Y, Nodasaka Y, Yumoto I (2013b) Oceanobacillus polygoni sp. nov., a facultatively alkaliphile isolated from indigo fermentation fluid. Int J Syst Evol Microbiol 63:3307-3312

Huß VAR, Festl H, Schleifer KH (1983) Studies on the spectrophotometric determination of DNA hybridization from renaturation rates. Syst Appl Microbiol 4:184-192

Kim YG, Choi DH, Hyun S, Cho BC (2007) Oceanobacillus profundus sp. nov., isolated from a deep-sea sediment core. Int J Syst Evol Microbiol 57:409-413

Kimura M (1980) A simple method for estimating evolutionary rates of base substitutions through comparative studies of nucleotide sequences. J Mol Evol 16:111-120

Lanyi B (1987) Classical and rapid identification methods for medically important bacteria. Methods Microbiol 19:1-67

Lee JS, Lim JM, Lee KC, Lee JC, Park YH, Kim CJ (2006) Virgibacillus koreensis sp. nov., a novel bacterium from a salt field, and transfer of Virgibacillus picturae to the genus Oceanobacillus as Oceanobacillus picturae comb. nov. with emended descriptions. Int J Syst Evol Microbiol 56:251-257

Lee S-Y, Oh T-K, Kim W, Yoon J-H (2010) Oceanobacillus locisalsi sp. nov., isolated from a marine solar saltern. Int $\mathrm{J}$ Syst Evol Microbiol 60:2758-2762

Lee DC, Kang H, Weerawongwiwat V, Kim B, Choi YW, Kim W (2013) Oceanobacillus chungangensis sp. nov., isolated from a sand dune. Int $\mathrm{J}$ Syst Evol Microbiol 63:3666-3671

Logan NA, Berge O, Bishop AH, Busse HJ, De Vos P, Fritze D, Heyndrickx M, Kämpfer P, Ventosa A et al (2009) Proposed minimal standards for describing new taxa of aerobic, endospore-forming bacteria. Int J Syst Evol Microbiol 59:2114-2121

Lu J, Nogi Y, Takami H (2001) Oceanobacillus iheyensis gen. nov., sp. nov., a deep-sea extremely halotolerant and 
alkaliphilic species isolated from a depth of $1,050 \mathrm{~m}$ on the Iheya Ridge. FEMS Microbiol Lett 205:291-297

Marmur J (1961) A procedure for the isolation of deoxyribonucleic acid from micro-organisms. J Mol Biol 3:208-218

Marmur J, Doty P (1962) Determination of the base composition of deoxyribonucleic acid from its thermal denaturation temperature. J Mol Biol 5:109-118

Murray RGE, Doetsch RN, Robinow CF (1994) Determinative and cytological light microscopy. In: Gerhardt P, Murray RGE, Wood WA, Krieg NR (eds) Methods for general and molecular bacteriology. American Society for Microbiology, Washington, pp 21-41

Nam JH, Bae W, Lee DH (2008) Oceanobacillus caeni sp. nov., isolated from a Bacillus-dominated wastewater treatment system in Korea. Int J Syst Evol Microbiol 58:1109-1113

Namwong S, Tanasupawat S, Lee KC, Lee J-S (2009) Oceanobacillus kapialis sp. nov., from fermented shrimp paste in Thailand. Int J Syst Evol Microbiol 59:2254-2259

Raats D, Halpern M (2007) Oceanobacillus chironomi sp. nov., a halotolerant and facultatively alkaliphilic species isolated from a chironomid egg mass. Int J Syst Evol Microbiol 57:255-259

Romano I, Lama L, Nicolaus B, Poli A, Gambacorta A, Giordano A (2006) Oceanobacillus oncorhynchi subsp. incaldanensis subsp. nov., an alkalitolerant halophile isolated from an A1gal mat collected from a sulfurous spring in Campania (Italy), and emended description of Oceanobacillus oncorhynchi. Int J Syst Evol Microbiol 56:805-810

Rzhetsky A, Nei M (1992) A simple method for estimating and testing minimum-evolution trees. Mol Biol Evol 9(5): 945-967

Saitou N, Nei M (1987) The neighbor-joining method: a new method for reconstructing phylogenetic trees. Mol Biol Evol 4:406-425

Schleifer KH (1985) Analysis of the chemical composition and primary structure of murein. Methods Microbiol 18: 123-156
Schleifer KH, Kandler O (1972) Peptidoglycan types of bacterial cell walls and their taxonomic implications. Bacteriol Rev 36:407-477

Smibert RM, Krieg NR (1994) Phenotypic characterization. In: Gerhardt P, Murray RGE, Wood WA, Krieg NR (eds) Methods for general and molecular bacteriology. American Society for Microbiology, Washington, pp 607-654

Tamura K, Peterson D, Peterson N, Stecher G, Nei M, Kumar S (2011) MEGA5: molecular evolutionary genetic analysis using maximum likelihood, evolutionary distance, and maximum parsimony methods. Mol Biol Evol 28(10):2731-2739

Thompson JD, Higgins DG, Gibson TJ (1994) CLUSTAL W: improving the sensitivity of progressive multiple sequence alignment through sequence weighting, position-specific gap penalties and weight matrix choice. Nucleic Acid Res 22:4673-4680

Tominaga T, An S-Y, Oyaizu H, Yokota A (2009) Oceanobacillus soja $\mathrm{sp}$. nov. isolated from soy sauce production equipment in Japan. J Gen Appl Microbiol 55:225-232

Ventosa A, Marquez MC, Kocur M, Tindall BJ (1993) Comparative study of "Micrococcus sp". strains CCM 168 and CCM 1405 and members of the genus Salinicoccus. Int J Syst Bacteriol 43:245-248

Ventosa A, Nieto JJ, Oren A (1998) Biology of moderately halophilic aerobic bacteria. Microbiol Mol Biol Rev 62:504-544

Xu DQ, Huang JJ, Zhang JZ, Fan Q, Liu DL (1995) Halomonas huanghaiensis sp. nov., a new species of genus Halomonas. Acta Microbiol Sin 35:315-321 (in Chinese)

Yang JY, Huo YY, Xu XW, Meng FX, Wu M, Wang CS (2010) Oceanobacillus neutriphilus sp. nov., isolated from activated sludge in a bioreactor. Int $\mathbf{J}$ Syst Evol Microbiol 60:2409-2414

Yumoto I, Hirota K, Nodasaka Y, Nakajima K (2005) Oceanobacillus oncorhynchi sp. nov., a halotolerant obligate alkaliphile isolated from the skin of a rainbow trout (Oncorhynchus mykiss), and emended description of the genus Oceanobacillus. Int J Syst Evol Microbiol 55:1521-1524 